Practice Reflections

\title{
Better integration of education and practice? Promoting research- based social work
}

\author{
Sisko Piippo ${ }^{1}$, Juha Hämäläinen ${ }^{2}$, Anssi Savolainen ${ }^{3}$, \\ Mari Suonio $^{3}$, and Raija Väisänen ${ }^{4}$
}

\begin{abstract}
This article deals with development work that aimed at promoting a better integration of social work university education and social work practice. The development work incorporated the academic world into the working life of social workers in rural areas. As a result, a permanent university-agency network was established, consisting of a university-coordinated networked infrastructure of 26 significant employer organisations (municipalities and nongovernmental organisations). Seminars, workgroups and a continuing education course for practice educators were modelled and realised as network activities. The network has enhanced collaboration. To support the aims of social work education to promote the use of scientific methods and techniques in practice, a significant structure for better interaction with the practice field has been created. Practitioners do have enthusiasm for development work and it is essential in terms of research-based social work as to how this is resourced, supported and utilised by educational solutions. However, in addition to the university-practice relationship, the relationship between individuals and their employer agencies is also key in terms of escalating learning into the organisational context.
\end{abstract}

Keywords: Social work education; research-based social work; practical training; networking

1. Doctoral Student, Faculty of Social Sciences and Business Studies

2. Professor, Faculty of Social Sciences and Business Studies

3. University Teacher, Faculty of Social Sciences and Business Studies

4. University Lecturer, Faculty of Social Sciences and Business Studies

Address for correspondence: Sisko Piippo, Faculty of Social Sciences and Business Studies, Dept of Social Sciences, University of Eastern Finland, P.O. Box 1627, FI-70211 Kuopio, Finland.piippo@student.uef.fi

Date of first (online) publication:

34 J. of Practice Teaching \& Learning 12(2), pp.xx-xx. DOI: 10.1921/6002120204. @ w\&-b 
Better integration of education and practice? Promoting research-based social work

\section{Introduction}

The gap between theory and practice is a matter of concern and a great challenge for education in perhaps all professions, but especially in practice-based disciplines. This article will discuss the collaborative developmental work between social work education and practice, which aims to advance the interaction between university and practice. To develop social work practice education, new connections between the academic world and practice were recommended by the Finnish Higher Education Evaluation Council (Korkeakoulujen arviointineuvosto, 2008) and by the Ministry of Education (Opetusministeriö, 2007). Findings from several papers (e.g. Clapton et al, 2008; Wilson \& Kelly, 2010) emphasised the insufficient integration of theory and practice in learning. Consequently, from the perspective of practitioners, applying research and practice has been considered as difficult (Bergmark \& Lundström, 2002; KarvinenNiinikoski, 2005; Osmond \& O'Connor, 2006). Naturally, this is worrying from the educational standpoint. Better integration of theory and practice could provide the tools that are necessary to meet with the challenges in practice and, thereby, promote research-oriented practice.

As Orme and Powell (2007, p. 989) aptly conclude, improving social work professional practice for the benefit of service users is (ultimately) the aim of the teaching and thus the definition of quality in research includes the utility of the research for practitioners. In the 2000s, the development of Finnish social work practice education, in terms of working-life relationships, was strongly invested in, and development projects that focused on establishing permanent structures between university and practice for shared learning and development arenas were launched in Finnish universities (Tuohino et al, 2012).

For example, various clinic-based teaching solutions are already underway in Finnish social work education. However, in the University of Eastern Finland, the development of practice education ${ }^{1}$ has aimed to find new types of links between the academic world and practice in rural areas. As a result, a structure for deeper collaboration, the Network of Researchbased Social Work Education Centres (NRSWEC), was established in 2010 to 2012. Three forms of network collaboration were modelled and organised: a continuing learning course for practice educators ${ }^{2}$, mutual discussion forums for students, university staff and practitioners and a pedagogical website. Although e-communication (a videoconference system, web-memos) was employed as an additional option for helping

35 J. of Practice Teaching \& Learning 12(2), pp.xx-xx. DOI: 10.1921/6002120204. @ wEb 
inter-provincial participation, seminars and workgroups were based on face-to-face-meetings. As of 2012, social work practice education has been integrated into this university-coordinated infrastructure of 26 organisations in Eastern and South-East Finland.

In general, practice education is not viewed as a distinct area in the development of these new structures of social work education in Finland. Instead, it has been merged as a part of the relationship that exists between research-based education and working life, where education, research and development are expected to be integrated within multi-stakeholder collaboration (Suonio \& Pohjola, 2012).

Knowledge is not understood merely as 'readily available' or 'traditional' information, which could be transferred directly in the form of books or research articles - for example, research-oriented Finnish social work education promotes the view that in addition to academic research, social work knowledge can be produced on working-life relationships (KarvinenNiinikoski, 2005; Hämäläinen, 2011; Tuohino et al, 2012). However, this view of research orientation as a tool for bridging the gap between social work theory and practice (Matthies, 2005, p. 276) emphasises the research capacity of practitioners. In Finland, researcher education is integrated into basic social work degrees (MAs). A qualified professional has the capability of applying theories and using research methods and has a critical, reflective and scientific way of thinking during problem-solving tasks (Karvinen-Niinikoski, 2005; Mäntysaari, 2005; Hämäläinen, 2011). Thus, research-based social work education aims to develop research capacity, which will be realised and utilised as research-based knowledge production in social work practice.

Various innovative experiments have been carried out in the area of social work and its practice education for better integration of academia and practice. In Scotland, the university educator's role as an 'academic adviser' during practical training courses has been highlighted (Clapton et al, 2008). In the U.K., the relationship between practice educators and students and its significance for learning have been discussed (Lefevre, 2005). McCrystal and Wilson's (2009) study aimed to develop research-minded practice in the UK. Reports of Finnish clinic-type social work practice education have been presented (e.g. Driessens et al, 2011; Karvinen-Niinikoski, 2005). A research capacity-building network has been established in British social work education (Orme \& Powell, 2007 p. 1000). The need to develop infrastructures between academia and practice has been recognised (Corby, 2006, p. 175; Bellinger, 2010, p. 2462). However, there has been less focus

36 J. of Practice Teaching \& Learning 12(2), pp.xx-xx. DOI: 10.1921/6002120204. (๑ w\&-b 
on collaborative development work, especially in rural areas. Our paper aims to contribute to this by presenting collaborative, network-based development work, which took into account both national administrative recommendations for practice education and more regional developmental needs.

\section{Finnish social work education}

The view that social work and social work education are subjected to the requirements of being evidence-based is anything but new. Research orientation and its different forms have also been central to the Finnish discussions about social work education since the 1980s. Based on an evaluation of social work education in Finland, in 2004, the Finnish Higher Education Evaluation Council stated the following:

Social work is a profession, a discipline and an operational system of the society that consists of research, education and practical social work, and interaction between these. The question is about professional actions based on research in order to prevent and relieve social problems.' (Korkeakoulujen arviointineuvosto, 2004, p. 32)

Currently, this research orientation is viewed as a basic pedagogical theme in Finnish social work (Karvinen-Niinikoski, 2005; Mäntysaari, 2010; Hämäläinen, 2011; Tuohino et al, 2012). In the University of Eastern Finland, courses on practice education and research methods are combined, and practical training is carried out within the framework of case studies and case evaluations (Niemelä, 2012). The research-orientation ideal covers the entire professional spectrum from academic study to practice, and realising this research-based practice requires practitioners who are capable of scientific problem solving and of creatively applying scientific theories (Karvinen-Niinikoski, 2005; Hämäläinen, 2011, p. 482). The ideal form is related to innovative knowledge production (Karvinen-Niinikoski, 2005), where different roles, originally defined by institutions (social workers, students and researchers), are thought to be mixed.

Accordingly, the concept of the research base refers to both the idea of producing a research-based knowledge base (theories, methods and information) and transferring this knowledge into practice by giving

37 J. of Practice Teaching \& Learning 12(2), pp.xx-xx. DOI: 10.1921/6002120204. @ wEbb 
students the tools to use research methods and a scientific way of thinking in practice (Hämäläinen \& Niemelä, 2007, p. 41); that is, tools for research-based knowledge production. Ultimately, the concept of research is understood in a broader way than 'merely' research undertaken with its traditional meanings and by traditional research institutions.

According to a follow-up evaluation report on Finnish social work university education in 2008 (Korkeakoulujen arviointineuvosto, 2008), there was no clear model of practice education, and social work education needed to be developed as a research-based branch, where theory, academic research and practice education would closely interact (Opetusministeriö, 2007).

\section{Developing the network for social work practice education}

To support the realisation of the above aims, and following both national and international discussions in social work science, the university-practice collaborative development work was expected to promote research-based social work by creating new links between social work education and practice. However, regarding practice education, the views and development needs of the large target area - identified as the Northern, peripheral, sparsely populated region of Finland - were not specifically known.

\section{Explorative surveys}

To shed light on such issues, Survey 1 was conducted in the planning stage. To explore the views on completed development work at the closing stage of the project, Survey 2 was targeted at social work practitioners (Tablel).

\section{Limitations}

The questionnaire targeting the social sector managers yielded a very low response rate of $35.9 \%$. The original social worker sample in the questionnaire is not known. Social managers in the target area were asked to deliver e-mail questionnaires to social workers in their organisations and 40 workers completed the questionnaire.

38 J. of Practice Teaching \& Learning 12(2), pp.xx-xx. DOI: 10.1921/6002120204. @ w\&bb 
Table 1

Methodology

\begin{tabular}{|c|c|c|c|c|c|c|}
\hline & $\begin{array}{l}\text { Target } \\
\text { group }\end{array}$ & $\operatorname{Aim}(\mathbf{s})$ & $N$ & $\begin{array}{l}\text { Response } \\
\text { rate }(\%)\end{array}$ & $\begin{array}{l}\text { Method and } \\
\text { data }\end{array}$ & Findings \\
\hline $\begin{array}{l}\text { Survey } \\
1 \\
\text { in } 2010\end{array}$ & $\begin{array}{l}\text { Middle-level } \\
\text { managers } \\
\text { Social } \\
\text { workers }\end{array}$ & $\begin{array}{l}\text { Development } \\
\text { possibilities } \\
\text { in practice } \\
\text { education }\end{array}$ & $\begin{array}{l}39 \\
\text { unknown }\end{array}$ & $\begin{array}{l}35.9 \\
\text { unknown } \\
\text { (40 } \\
\text { responses) }\end{array}$ & $\begin{array}{l}\text { In both surveys: } \\
\text { Numeric } \\
\text { information: } \\
\text { Statistical (SPSS) } \\
\text { description } \\
\text { Qualitative data: } \\
\text { collected, coded, } \\
\text { categorised and } \\
\text { analysed by theme }\end{array}$ & $\begin{array}{l}\text { Presented in } \\
\text { chapter: } \\
\text { Findings: } \\
\text { Practitioners' views } \\
\text { of practice } \\
\text { education }\end{array}$ \\
\hline $\begin{array}{l}\text { Survey } \\
2 \\
\text { in } 2012\end{array}$ & $\begin{array}{l}\text { Contact } \\
\text { persons in } \\
\text { NRSWEC } \\
\text { organisations }\end{array}$ & $\begin{array}{l}\text { The first } \\
\text { experiences } \\
\text { of the } \\
\text { NRSWEC }\end{array}$ & 28 & 60.4 & & $\begin{array}{l}\text { Presented in } \\
\text { chapter: } \\
\text { Implications: } \\
\text { Network of } \\
\text { Research-based } \\
\text { Social Work } \\
\text { Education Centres } \\
\text { (NRSWEC) }\end{array}$ \\
\hline
\end{tabular}

Survey 2 included only subjective reporting by network contact persons, but these individuals are viewed as the representatives of their organisations. For an overall picture of the NRSWEC and its activities, a study targeting all social workers and social work students in the network area will be needed in the near future.

\section{Findings: Practitioners' views of practice education}

In general, findings were positive in terms of research-based social work education and enthusiasm for shared development was expressed.

\section{Current university collaboration}

Social workers were asked to grade co-operation with the university on a 4-point scale, ranging from 1 (insufficient) to 4 (very good). Forty-six per cent felt that co-operation worked well. Qualitative responses clarify deficiencies located around the dialogue between theory and practice. Previously, the co-operation was based mainly on students' practice training. The respondents hoped for greater co-operation between the university and practice. Several qualitative answers noted the need

39 J. of Practice Teaching \& Learning 12(2), pp.xx-xx. DOI: 10.1921/6002120204. @ w\&bb 
for support in supervising students. This would also act to strengthen teaching and development capacity. Social workers and managers found continuing education - especially continuing education that targeted practice educators - a very useful form of collaboration with universities. A university-coordinated, networked infrastructure of organisations was considered as a good route for developing a new kind of co-operation and 97\% of organisations were interested in joining.

\section{Practical training}

According to managers, $93 \%$ of organisations were ready to offer practicetraining placements for students. They were seen as the qualified social workers of the future, and practice training was viewed as a way of ensuring competent personnel. Overall, in best-case scenarios, the students were seen as a resource, allowing the social workers to critically reflect on their own work, workplace and ethics. Social workers found supervising to be a useful tool for developing their teaching and their skills, and as a motivator in developing their own work. However, they found the lack of resources (time, workspace, personnel) problematic. Yet $43 \%$ of social workers said they would act as a practice educator in the future and $48 \%$ reported their willingness to participate in planned continuing education courses for practice educators. Seventy per cent of social workers had acted as a student's practice educator at least once, and their supervising capability was mainly reported as good. Some considered that supervising reduced (15\%) or increased (23\%) their ability to cope with their own work, but the majority (38\%) reported no impact.

However, small rural municipalities reported that their distance from the university and the limited economic resources were barriers to recruiting students and restricted the deployment of development projects. These small municipalities offering unpaid practical training places are not viewed as attractive by students. This was deemed to be a problem, because students were seen as the qualified social workers ${ }^{3}$ of the future and the area suffers due to a lack of qualified staff. According to the Provincial Government of Eastern Finland (Itä-Suomen lääninhallitus, 2008), in $72 \%$ of cases in this area, vacancies were filled part of the time or all of the time by temporary staff, and in $20 \%$ of municipalities (small, under 6,000 citizens), there were no qualified social workers at all. The lack of permanent qualified workers is a matter of concern in terms of research-based social work.

40 J. of Practice Teaching \& Learning 12(2), pp.xx-xx. DOI: 10.1921/6002120204. @ w\&bb 
Some municipalities have never had any student placements. Due to the distances involved, a networked model of collaboration was hoped for by managers. The need for a regional model for helping to recruit social workers was presented. In addition, social workers in these peripheral locations hoped for more regional networking.

\section{Attitudes towards research and development issues}

From the viewpoint of the collaborative development of research-based social work education, the results are promising (Table 2).

Table 2

Social workers' development and teaching capacity (\%)

\begin{tabular}{|c|c|c|c|c|c|}
\hline Interested in: & Very much & Much & Some & Little & $\begin{array}{l}\text { Not } \\
\text { at } \\
\text { all }\end{array}$ \\
\hline Collaboration with university & 20 & 38 & 30 & 10 & \\
\hline Developing work methods & 35 & 43 & 23 & & \\
\hline Research relating to own work & 18 & 50 & 23 & 8 & 3 \\
\hline $\begin{array}{l}\text { Research-based knowledge } \\
\text { production }\end{array}$ & 18 & 40 & 25 & 15 & \\
\hline $\begin{array}{l}\text { Strengthening own skills as } \\
\text { supervisor and developer }\end{array}$ & 18 & 35 & 38 & 8 & \\
\hline $\begin{array}{l}\text { Project-based development work with } \\
\text { university }\end{array}$ & 15 & 30 & 35 & & \\
\hline Post-graduate studies & 5 & 18 & 38 & 20 & 20 \\
\hline Continuing education & 18 & 45 & 30 & 5 & 3 \\
\hline $\begin{array}{l}\text { Giving an expert speech at an } \\
\text { education event }\end{array}$ & 5 & 10 & 35 & 23 & 25 \\
\hline $\begin{array}{l}\text { Supervising work groups or seminars } \\
\text { relating to practice education }\end{array}$ & 8 & 15 & 25 & 25 & 28 \\
\hline Lecturing in university & 13 & 5 & 28 & 28 & 28 \\
\hline
\end{tabular}

Social workers' interest towards collaboration, research, research-based knowledge production and development was relatively high. Interest was highest in the development of their own work methods. Moreover, they viewed both post-graduate studies and continuing education as possible ways of developing their existing skills. However, the results are mixed. Project-based development and academic knowledge production in seminars or work groups were seen mainly as unimportant; so was participating in teaching in university. This participation of practice workers could be very useful, however, for enriching the learning experiences of

41 J. of Practice Teaching \& Learning 12(2), pp.xx-xx. DOI: 10.1921/6002120204. @ wEb 
students and vice versa. To sum up, research-based knowledge relating to one's own work was seen as very important, but in addition to traditional academic knowledge production, more collaboration and new easy-access arenas were needed for its realisation.

The following questions sought information about useful issues regarding practice education in terms of practical work (Table 3).

Table 3

Important issues for students to learn about during practice education (\%)

\begin{tabular}{|c|c|c|c|c|c|}
\hline & $\begin{array}{l}\text { Very } \\
\text { important }\end{array}$ & Important & $\begin{array}{l}\text { No } \\
\text { opinion }\end{array}$ & $\begin{array}{l}\text { Somewhat } \\
\text { important }\end{array}$ & Not important \\
\hline Interactional skills & 80 & 13 & & 5 & \\
\hline Professional ethics & 70 & 25 & & & \\
\hline Multi-agency working & 63 & 30 & & 8 & \\
\hline Methods of client work & 55 & 35 & & & \\
\hline Networking skills & 53 & 33 & & 13 & \\
\hline Social welfare legislation & 50 & 40 & & 5 & \\
\hline Practices of social security & 35 & 58 & & & \\
\hline Societal influence & 25 & 35 & 3 & 35 & \\
\hline $\begin{array}{l}\text { Development work } \\
\text { and social planning }\end{array}$ & 15 & 43 & 3 & 35 & 3 \\
\hline Project knowledge & 3 & 38 & 5 & 45 & 3 \\
\hline $\begin{array}{l}\text { Research-based knowledge } \\
\text { production }\end{array}$ & 8 & 58 & 5 & 25 & 5 \\
\hline Administrative management skills & & 35 & & 40 & 18 \\
\hline
\end{tabular}

Research-based knowledge production was seen as important, but not as important as the social workers' own interests. Even if social workers were interested in development, research and research-based knowledge production (Table 2), these were, however, seen as not such necessary or needed skills when it came to practice and to the job description of a basic social worker. How had social workers understood the concept of researchbased knowledge production? Seventy-nine per cent of respondents used the professional title of social worker. As a possible explanation, concepts of research and development were linked to so-called special social workers, with, for example, the professional title of practitioner-researcher. However, the concept of research-based social work highlights the capability of all practitioners, without a specific professional title, to use scientific methods and thinking in their practice. In the future, the merging of client work skills and research-based knowledge production should be promoted. This result lends support to the studies of Karvinen-Niinikoski (2005) and Driessens et al. (2011), according to which, everyday professional practices should be integrated more with research-based knowledge production.

42 J. of Practice Teaching \& Learning 12(2), pp.xx-xx. DOI: 10.1921/6002120204. ( wEb 
Practice education in workplaces should also be linked more to research and development issues.

Skills relating to client work were ranked as the most important, whereas management and project work were seen as less important. This also reflects social workers' own interests (Table 2). The majority considered knowledge of social security practices and social welfare legislation as very important. This can be understood in the context of the Finnish social policy and welfare system. Social services - based on law - are provided mainly by the public sector, where the majority of social workers are employed (Meeuwisse et al., 2011).

\section{Implications: Network of Research-based Social Work Education Centres (NRSWEC)}

Considering the special needs of the area, a university-coordinated networked infrastructure of 26 organisations was created. Each organisation formed a research-based social work education centre with a university. This network of 26 centres - viewed as a social innovation for collaboration between the field of practice and the academic world - is also expected to expand in the future.

The research-related NRSWEC activities - a continuing education course for practice educators, mutual discussion forums and a pedagogical website - were developed as new arenas for promoting the ideal of collaborative, research-based knowledge production. They are presented below with the findings from Survey 2 (see Table 1 for additional information on Survey 2) and the evaluation of the continuing education course (Savolainen et al., 2012).

\section{Continuing learning for practice educators}

Due to social workers' interests (Table 2), a continuing education course was organised. The first continuing learning course targeted practice educators in workplaces. It was held in 2011 and comprised both Internet-based and traditional education. The course was based on the ideas of life-long, co-operative and reforming learning, with critical reflection as the 'learning method'. Practice teachers were educated in student guidance, mentoring,

43 J. of Practice Teaching \& Learning 12(2), pp.xx-xx. DOI: 10.1921/6002120204. @ wEb 
self-management and development work in the workplace from the point of view of research-based social work. Experiences were very positive, even if the basic work situation was too pressurised in some cases. A clear need for experienced mentor groups for practice educators was expressed. Mentor groups were thought to support the organisations' own work in coaching or counselling. Those contacted hoped that topics such as these would be anchored more in the field. They also noted a need for deeper collaboration during practical education courses. The willingness to give the organisation's practical expertise in use by participating in social work courses was also expressed (Savolainen et al., 2012). In the future, continuing learning courses will be held every second year.

\section{Mutual discussion forums for practitioners, students and university staff}

In 2012, easy-access forums were held for up-to-date, free and goal-oriented discussions about the research and development of client work and regional well-being in the form of seminars and thematic research work groups led by university staff. In total, $87 \%$ of organisations participated in the forums (seminars and/or workgroups). Such forums enabled social workers to become familiar with the latest, relevant client-related research findings, in addition to exploring the possibilities for shared development work. They also facilitated discussions on regional development needs, which could then be researched by the university. Shared seminars and workshops are also a shared learning environment, where views and experiences of practitioners enrich the students' learning experiences and vice versa. Like the continuing education course, these forums were also expected to give rise to discussions and reflections in workplaces. Interesting lectures and reflective discussions with other participants were felt to be very useful. In future, students should be motivated more to participate.

\section{Pedagogical website}

The project established a new website to act as a pedagogical portal for connecting students, researchers and network partners. The website ensures easier access to and use of research information. It also includes information on vacancies, education structure and material for practice education.

44 J. of Practice Teaching \& Learning 12(2), pp.xx-xx. DOI: 10.1921/6002120204. (๑ w\&-b 
The majority of respondents (88\%) were familiar with the website of the NRSWEC. They mostly used the website to search for presentations about the NRSWEC, for information about social work practical education, research and development and for contacts. In addition, they used it for recruitment. Twenty-four per cent of organisations posted notifications of vacancies for practical education. The website development is an on-going process, reflecting practice training and research.

\section{Attitudes towards the NRSWEC}

Perhaps due to fact that the network has only just been established, the network's ability in terms of recruiting workers was estimated to be relatively low. Naturally, the lack of social workers in Finland cannot be solved merely through educational solutions. This shortage is also linked to issues such as low salaries and excessive workloads, which should be tackled at the governmental level. However, an essential point raised by a strong majority of the cohort was that co-operation was improving. The qualitative data showed that, in some cases, there was a long history of co-operation with universities, but that the networked infrastructure opened up a new channel for a deeper co-operation. Shared development work was identified as the main theme in relation to the most useful form of co-operation in the future.

Table 4

View of the NRSWEC as an arena for collaboration

\begin{tabular}{lccccc}
\hline & $\begin{array}{c}\text { Strongly } \\
\text { agree }\end{array}$ & Agree & No opinion & Disagree & $\begin{array}{c}\text { Strongly } \\
\text { disagree }\end{array}$ \\
\hline $\begin{array}{l}\text { The co-operation between universities is } \\
\text { improving }\end{array}$ & 76 & 24 & & \\
$\begin{array}{l}\text { The network may be used as a tool to enhance } \\
\text { social workers' knowledge base }\end{array}$ & 47 & 29 & 24 & \\
$\begin{array}{l}\text { Research is becoming more important for } \\
\text { practice }\end{array}$ & & & & \\
Scientific issues are discussed more & 24 & 41 & 35 & 24 \\
$\begin{array}{l}\text { Attitudes towards students are more positive } \\
\text { Attracting students will be easier in the future }\end{array}$ & & 47 & 41 & 18 \\
$\begin{array}{l}\text { Obtaining qualified workers will be easier in the } \\
\text { future }\end{array}$ & 6 & 35 & 41 & 18 \\
\hline
\end{tabular}

Findings showed that even if the significance of research for practice was recognised, and even with the majority of organisations participating in NRSWEC activities (with this participation being considered as useful),

45 J. of Practice Teaching \& Learning 12(2), pp.xx-xx. DOI: 10.1921/6002120204. @ wE-b 
$24 \%$ still disagreed or had no opinion concerning the meaning of scientific issues (35\%) and research (24\%) in workplaces, viewing the network as perhaps not having changed anything (Table 4). This need for better interaction between individuals and organisations was also noted in Beddoe's (2009) study of learning organisations; practitioners reported intellectual refreshment, critical reflection and acknowledging successful work, more simply put, the listening and 'talking' in organisations, as prerequisites for 'learning workplaces'.

\section{The NRSWEC as a tool for collaboration}

Focusing on the better integration of education in practice and the academic world, this paper sheds light on the significance of the collaborative development and permanent structures between academic institutions and social work practice. It is too early for a total evaluation of the NRSWEC. However, at this stage, the following issues can be presented:

1. The networked infrastructure is a functional model for better interaction between universities and the social work agencies in rural, sparsely populated areas.

Findings suggest that social workers in the field were interested in developing the work on students' practice education, but that deeper collaboration with the academic world was hoped for as a prerequisite for opening up new links between universities and practice. Results indicate that for promoting the ideal of research-based knowledge production, a network with open easy-access arenas, continuing education and thematic research workgroups would best serve the development needs of the target area. In response to this, a networked infrastructure of 26 organisations was established. A strong majority found that the collaboration was improved, which is also supported by the fact that participation in the research-related events was high. This paper contributes to some earlier studies on social work education, which have highlighted the collaboration with the field of practice in terms of creating structures for knowledgecreating communities and networks in Finland (e.g. Drienssens et al., 2011) as well as in the U.K. (e.g. Clapton et al., 2010; McCrystal \& Wilson, 2009; Orme \& Powell, 2007).

46 J. of Practice Teaching \& Learning 12(2), pp.xx-xx. DOI: 10.1921/6002120204. @ w\&b 
2. Practitioners' enthusiasm for development work should be supported and they should be encouraged more to participate in teaching, both in the field and also in the academic world.

Predictably, findings in Table 3 suggest that research-based knowledge production and development were not seen as an important part of the job description for social workers; results are similar to the majority of papers relating to the research-based knowledge of social workers (e.g. Bergmark \& Lundströn, 2002; Osmond \& Connor, 2006). As an important notion, however, social workers' interest towards research and developmental issues in terms of their own work was high (Table 2), which is important for the development of research-oriented practice, and this should be taken more notice of in education as well as in future research. In education, the merging of client work skills and research-based knowledge production need to be promoted and practical training should be linked more to research and development issues in workplaces. To increase the scientific focus of practical training, continuing education for practice educators is, in itself, definitely a valuable resource for social work education through building practitioners' supervising capacity.

A challenge is, however, in social workers linking developmental and research-related issues primarily to the vacancies for so-called special social workers (practitioner-researchers, developmental social workers). Another risk involves supervision only being delegated to specific persons; to those practice educators who have passed a continuing education course, for instance.

3. Organisational challenges

Undoubtedly, persons in specific roles and vacancies in organisations can act as catalysts for promoting and utilising research at the organisational level (Orme \& Powell, 2007). Thus, the role of special social workers in organisations is related to disseminating knowledge, and establishing vacancies for special professional titles can be understood as a step towards research-based social work practice, where the research and development component will be integrated into the job description of all social workers (Barnardo's, 2000). However, without the common drive to develop work as a community-based endeavour, the responsibility for the development and research-oriented work in organisations will stay at the individual level (personified only in those appointed as special social workers).

47 J. of Practice Teaching \& Learning 12(2), pp.xx-xx. DOI: 10.1921/6002120204. @ wEb 
Findings revealed that much more development is needed to secure the commitment of organisations as communities valuing learning and development. The starting points and circumstances of this social work educational development work are challenging. For instance, the Ministry of Education in Finland (Opetusministerio, 2007, p. 28) stated that social work education and practice have not developed at the same rate: some of the oldest structures and cultures of organisations do not recognise the importance of knowing and of knowledge produced by a renewed education system. Yet, it is clearer than ever that educational and scientific support is needed more in practice when wide-reaching reforms are to be launched in the public sector; for example, to avoid 'mismatches between the map and terrain' and top-down, excessive bureaucracy-driven development work (Bergmark et al, 2012). All in all, it is easy to agree with Orme and Powell (2007), who suggest that in order to increase the awareness and utilisation of social work research in organisational learning, new culture change across the social work community (including both researchers and the users of research) is needed.

When it comes to the academic world, the NRSWEC demands resources, for example, when considering the role of the university in the process of escalating and realising the individual learning experiences of educators, social workers and students in the level of research, via students' theses or other larger scale studies or development projects.

4. The potential of working-life relationships should be utilised and should expand more in social work education.

In spite of the organisational obstacles and limited resources, going further than organising continuing education programmes and seminars, networks do have the potential to address the insufficient integration between academia and practice (Orme \& Powell, 2007). The main idea of the NRSWEC - developing networked structures between education and practice - can also be localised within the context of research capacity-building networks (Orme \& Powell, 2007), which, in turn, have similarities with learning networks. As an essential difference to other networks, a learning network is created for learning and its primary function is to produce learning activities for new knowledge production (Knight \& Pye, 2005). Learning networks utilise networks to respond to the growing need for co-operation between working life and research institutes, and their focus is on bringing together actors

48 J. of Practice Teaching \& Learning 12(2), pp.xx-xx. DOI: 10.1921/6002120204. (๑ w\&-b 
with a sufficiently broad diversity of expertise, but who share an interest in a sufficiently similar development issue, and this group of actors may consist of work organisations, researchers, students and/or regional agencies (Alasoini, 2011, p. 18). In the networks of different stakeholder organisations, relocation of the institutional boundaries provides new approaches and possibilities to the shared development work of the academic world and practice. Thereby, the roles of student, educator and practitioner are able to be re-shaped. However, various issues need to be considered.

Orme and Powell (2007) speak on behalf of establishing learning infrastructures, but they ask, however, how integration can be achieved across all levels within organisations. In the discourse on learning networks created via projects, this same phenomenon is cited as the poor generative capacity of learning outcomes, referring to the deficiencies in escalating individual learning experiences to the larger organisational level (Alasoini, 2011).

To sum up, this is, and will also be a matter of concern in the development of the NRSWEC. Without underestimating the individual learning experiences that are likely achieved via participation in the research-related activities of the NRSWEC, the commitment of the organisations - including universities - as communities participating in research-based social work development, need to be strengthened in order to increase the internal generative capacity of the NRSWEC. This lack of generative capacity has also been reported in earlier Finnish social work education development work, which, however, emphasises more centre- and clinic-based models in collaboration with the field of practice (Muukkonen et al, 2012).

\section{The outlook for the integration of education and practice}

Significant infrastructure linking practice and the academic world has been established to support the realisation of the aims of research-based social work. Figure 1 overleaf illustrates the integration of the academic world and practice.

The NRSWEC operates along the practice-university boundary lines. Knowledge transfer from the academic world to practice and vice versa is

49 J. of Practice Teaching \& Learning 12(2), pp.xx-xx. DOI: 10.1921/6002120204. @ w\&b 
Figure 1.

The NRSWEC in its ideal form as an integrated space for shared learning

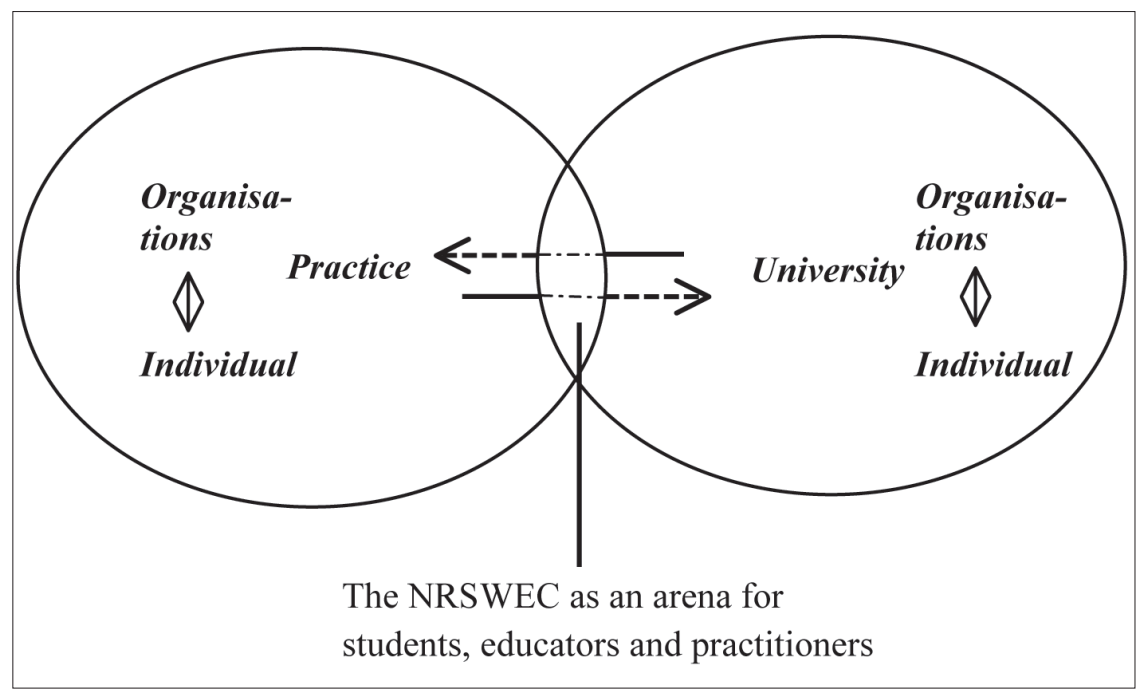

not direct. Instead, knowledge and roles (student, practitioner, researcher and educator) are mixed and re-produced at the boundaries and can then be utilised in a new form by institutions. The future of the NRSWEC depends on how this crossover area can be resourced, organised and utilised - by educators, researchers, students and practitioners. In addition to the relationship between academia and practice, it is also a question of interaction between individuals and the working organisations, both in the academic world and practice.

\section{Notes}

1 Practice education consists of university teaching (seminars, lectures) and three periods of practical training in workplaces (35 days during the Bachelor's Degree and 60 days during the Master's Degree).

2 The term 'practice educator' is also known elsewhere as a 'supervisor' or 'tutor'.

3 The five-year Master's Degree in Social Sciences. 


\section{References}

Alasoini, T. (2011) Learning networks as an infrastructure for the creation and dissemination of workplace innovation: an introduction. in Alasoini, T., Lahtonen, M., Rouhiainen, N., Sweins, C., Hulkko-Nyman, K., \& Spangar, T. (2011) (Eds.) Linking Theory and Practice - Learning Networks at the Service of Workplace Innovation. Helsinki (pp.13-30)

Barnardo's (2000). Linking Research and Practice. York: Joseph Rowntree Foundation [Accessed 14 February 2013 at http://www.jrf.org.uk/publications/linkingresearch-and-practice ]

Beddoe, L. (2009) Creating continuous conversation: social workers and learning organisations. Social Work Education, 28, 7, 722-736

Bergmark, A., Bergmark, A., \& Lundström, T. (2012). The mismatch between the map and terrain - evidence-based social work in Sweden. European Journal of Social Work, 15, $598-609$

Bergmark, Å. \& Lundström, T. (2002) Education, practice and research: knowledge and attitudes to knowledge of Swedish social workers. Social Work Education, 21, 3, 359-373

Clapton, G., Cree, V. E., Allan, M., Edwards, R., Forbes, R., Irwin, M., Macgregor, C., Paterson, W., Brodie, I., \& Perry, R. (2008) Thinking 'outside the box': a new approach to integration of learning for practice. Social Work Education, $27,3,334-340$

Corby, B. (2006) Applying Research for Social Work Practice. Berkshire: Open University Press

Driessens, K., Saurama, E., \& Fargion, S. (2011) Research with social workers to improve their social interventions. European Social Work, 14, 1, 71-88

Hämäläinen, J. and Niemelä, P. (2007) Aspects of research of social work in Finland. in Adams, A., Erath, P., \& Jovelin, E., (Eds.) Social Work and Science - An Uneasy Relationship? ERIS with Albert Publisher, University of Ostrava (pp. 35-56)

Hämäläinen, J. (2011) Social work as a research-based profession: opportunities, prerequisites and restrictions. Sociology Study, 7, 1, 473-483

Itä-Suomen lääninhallitus. (2008) Itä-Suomen läänin kuntien sosiaalityöntekijätilanne [The current situation relating to social workers in Eastern Finland]. Itä-Suomen lääninhallituksen julkaisuja [The Provincial Government of Eastern Finland, series 154]

Karvinen-Niinikoski, S. (2005) Research orientation and expertise in social work: challenges for social work education. European Journal of Social Work, $8,3,259-271$

51 J. of Practice Teaching \& Learning 12(2), pp.xx-xx. DOI: 10.1921/6002120204. @ wEb 
Knight, L. and Pye, A. (2005) Network learning: an empirically derived model of learning by groups of organizations. Human Relations, 58, 369-392

Korkeakoulujen arviointineuvosto (2004) Eettisyyttä, Elastisuutta ja Elämää - Yliopistojen sosiaalityön ja Ammattikorkeakoulujen Sosiaalialan koulutusten Arviointi Yhteistyössä Työelämän Kanssa (Ethicality, Elasticity and Life - Evaluation of University and Polytechnic Training in Co-operation with the Working Life Representatives), Helsinki: Korkeakoulujen arviointineuvoston julkaisuja [Finnish Higher Education Evaluation Council]

Korkeakoulujen arviointineuvosto (2008) Sosiaalityön ja sosiaalialan koulutuksen nykytila ja kehittämishaasteet. Yliopistojen sosiaalityön ja ammattikorkeakoulujen sosiaalialan koulutuksen seuranta-arviointi [The current state and development challenges of social work and the social sector. The follow-up evaluation of university and polytechnic training]. Helsinki: Korkeakoulujen arviointineuvoston julkaisuja [Finnish Higher Education Evaluation Council]

Lefevre, M. (2005) Facilitating practice learning and assessment: the influence of relationship. Social Work Education, 24, 5, 565-583

Mäntysaari, M. (2005) Propitious omens: Finnish social work research as a laboratory of change. European Journal of Social Work, 8, 3, 247-258

Matthies, A-L. (2005) Between science, practice and politics: practice research as a defining approach of social work research. European Journal of Social Work, $8,3,273-278$

McCrystal, P. and Wilson, G. (2009) Research training and professional social work education: developing research-minded practice. Social Work Education, $28,8,856-872$

Meeuwisse, A., Scaramuzzino, R., \& Swärd, H. (2011) Everyday realities and visionary ideas among social workers in the Nordic countries: a matter of specialization and work tasks? Nordic Social Work Research, 1, 1, 5-23

Muukkonen, T., Yliruka, L., \& Saurama, E. (2012) Praksis-toiminnalla oppivaa käytäntöä ja kumuloituvaa tietoa [Learning practice and cumulating knowledge via Praksis]? in Tuohino, N., Pohjola, A. \& Suonio, M. (Eds.) Sosiaalityön käytännönopetus liikkeessä [Social Work Practice Education in Motion]. SOSNET, Series 5 (pp. 196-212)

Niemelä, P. (2012) Tapauskohtaisuus sosiaalityössä [Case study - case work - case evaluation] Prosessimalli sosiaalityön ja sen käytännön opetuksen jäsentäjänä [Case-thinking in social work: the process model 'case study - case work - case evaluation' as a structure of social work practice education] in Tuohino, N., Pohjola, A. \& Suonio, M. (Eds.) Sosiaalityön käytännönopetus liikkeessä [Social Work Practice Education in Motion]. SOSNET, Series 5 (pp. 20-35)

52 J. of Practice Teaching \& Learning 12(2), pp.xx-xx. DOI: 10.1921/6002120204. @ w\&bb 
Better integration of education and practice? Promoting research-based social work

Opetusministeriö (2007) Sosiaalialan korkeakoulutuksen suunta [The orientation of social work in higher education]. The Ministry of Education, Report no. 43

Orme, J. and Powell, J. (2007) Building research capacity in social work: process and issues. British Journal of Social Work, 38, 5, 988-1008

Osmond, J. and O'Connor, I. (2006) Use of theory and research in social work practice: implications for knowledge-based practice. Australian Social Work, 59, 1, 5-19

Savolainen, A., Suonio, M., \& Väisänen, R. (2012) Käytännönohjaajaksi sosiaalialalle koulutettujen kokemuksia ohjaustietojensa ja -taitojensa kehittymisestä [Experiences of skill and knowledge development of social workers in continuing courses for practice teachers] in Tuohino, N., Pohjola, A. \& Suonio, M. (Eds.), Sosiaalityön käytännönopetus liikkeessä [Social Work Practice Education in Motion]. SOSNET, Series 5.

Suonio, M. and Pohjola, A. (2012) Mihin suuntaan tutkimusperustainen käytännönopetus on muuttumassa [In which direction is the research-based practice education about to change]? in Tuohino, N., Pohjola, A. \& Suonio, M. (Eds.) Sosiaalityön käytännönopetus liikkeessä [Social Work Practice Education in Motion]. SOSNET, Series 5 (pp.159-176)

Tuohino, N., Pohjola, A., \& Suonio, M. (2012) (Eds.) Sosiaalityön käytännönopetus liikkeessä [Social Work Practice Education in Motion]. SOSNET, Series 5.

Tuohino, N., Pohjola, A., \& Suonio, M. (2012) Sosiaalityön käytännönopetus kohti tutkimusperustaista työelämäsuhteissa oppimista [Social work practice education: towards research-based learning in work life] in Tuohino, N., Pohjola, A. \& Suonio, M. (Eds.) Sosiaalityön käytännönopetus liikkeessä [Social Work Practice Education in Motion]. SOSNET, Series 5 (pp. 8-18)

53 J. of Practice Teaching \& Learning 12(2), pp.xx-xx. DOI: 10.1921/6002120204. @ wEb 